\title{
Hang Wu Tang* \\ Charitable Organizations in Singapore: From Clan Based to State Facilitated Endeavors
}

https://doi.org/10.1515/npf-2021-0032

Received July 27, 2021; accepted December 20, 2021

Abstract: Singapore, with a five million population, has a vibrant charitable sector with over 2000 registered charities attracting approximately USD $\$ 2.18$ billion in annual donations. How did Singapore's charitable sector achieve its current level when it has been, in the past, segregated along mainly religious, race and clanbased communities? This paper explores this question by piecing together the current ecosystem, regulatory and tax infrastructure which facilitates the charitable sector in Singapore. Central to the development of the charitable sector has been the Singapore government's role of being a gatekeeper, regulator and enabler of charities. In analysing the government's role in the charitable sector, this paper locates Singapore's charitable sector within the literature on government and nonprofit organization relations which has been described at times being cooperative, complementary, confrontational, and co-optive. These astute observations ring true with respect to the Singapore government's relationship with the charitable sector. For organizations which pursue purposes consistent with state's vision of public good, the state's relationship with these charities has been largely cooperative and complementary. However, even within charities considered by the state to further public good, there is a strong element of co-optation where the state wields significant direct and indirect power over the charitable sector by way of provision of funding and board composition. In contrast, nonprofit organizations which engage in aims inconsistent with the state's perceived public interest are, by law, unable to register itself as charities and enjoy corresponding fiscal benefits. Such nonprofit organizations also typically do not receive state funding. This demonstrates the confrontational nature of the state's relationship with these nonprofit organizations. Through a close analysis of the laws, codes, media reports and academic literature on the charitable sector, the central thesis of this paper is that the charitable sector in Singapore is essentially a state facilitated endeavor.

Keywords: third sector, charity law, charity regulations, Singapore, government/ nonprofit relations

\footnotetext{
*Corresponding author: Hang Wu Tang, Yong Pung How School of Law, Singapore Management University, 55 Armenian Street, Singapore 179943, Singapore, E-mail: hwtang@smu.edu.sg. https://orcid.org/0000-0001-7785-5144
}

Ә Open Access. ๑ 2021 Hang Wu Tang, published by De Gruyter. ((c))BY the Creative Commons Attribution 4.0 International License. 


\section{Introduction}

Singapore, with a five million population, has a vibrant charitable sector with over 2000 registered charities attracting $\mathbf{S} \$ 2.9$ billion (approximately USD $\$ 2.18$ ) in annual donations (Charities Unit 2019). A recent international study ranks Singapore as one of the top two jurisdictions (along with Taiwan) in Asia within the 'Doing Well' cluster with the most favourable enabling conditions for private capital to meet societal needs (Centre for Asian Philanthropy and Society 2020). How did Singapore's charitable sector achieve its current level? The success of the charitable sector appears to be driven by the state's relationship with charities where the state enacted a robust regulatory framework which seeks to engender public trust in the sector and the presence of enabling organizations in the country which facilitates certain forms of charitable endeavours. This paper explores the state's role in promoting the charitable sector by piecing together the current ecosystem, regulatory and tax infrastructure which facilitates the charitable sector in Singapore. In analysing the state's role, this paper locates Singapore within the literature on government and nonprofit organization relations which has been described as at times cooperative, complementary, confrontational and co-optation (Najam 2007).

As a preliminary matter, there is the issue of clarifying the terms used in this paper. The term "charity" is used throughout this paper to describe organizations focusing on benevolence in the English common law tradition because Singapore used to be a former colony. As will be demonstrated below, there is a technical legal meaning to qualify as a registered charity in Singapore. If an organization is registered as a charity in Singapore, there will be substantial fiscal and other benefits which might include funding from the Singapore government. The term "nonprofit organizations" is used to describe voluntary and nonprofit activities in general which might include a range of political activities adjacent to the institution of the state. Thus, nonprofit organizations may include registered charities under this definition in Singapore. But in Singapore not all nonprofit organizations are registered charities because the purpose of the nonprofit organization may not be consistent with the legal definition of a charity under Singapore law. For example, groups of people pursuing the goal of abolishing the death penalty in Singapore would unlikely be able to register itself as a charity because under Singapore law this might not be regarded as a charitable purpose. In other words, the law in Singapore functions as a gatekeeper as to which organization may be regarded as a registered charity and enjoy corresponding benefits.

This paper draws from a study of the laws and regulations, media reports, annual reports of organizations and scholarly literature on the charitable sector 
in Singapore. While media and annual reports of organizations may present the state's narrative of the charitable space, this paper takes a critical analysis of the legal framework affecting charities and demonstrates the pervasive control the state wields over the charitable sector. Previous studies on the regulatory framework affecting charities have mainly centred around the provisions of the Charities Act without a detailed examination of the enabling organizations and state's policies in regulating and facilitating the charitable sector (Leow 2012; Tan 2007). Thus, this paper contributes to the pre-existing literature by presenting a holistic and critical analysis of the law and policies affecting the charitable sector.

Central to the development of the charitable sector has been the Singapore government's role of being a gatekeeper, regulator and enabler of charities. Najam has provided a universal model to describe the state's relationship with nonprofit organizations. He argues that this complex relationship is at times cooperative, complementary, confrontational and co-optative (Najam 2007). These astute observations ring true with respect to the Singapore government's relationship with the charitable sector and nonprofit organizations. For organizations which pursue purposes consistent with state's vision of public good, the state's relationship with these charities has been largely cooperative and complementary. However, even within these charities, there is a strong element of co-optation where the state wields significant power over the charitable sector. Co-optation of charities is particularly relevant in terms of the state's pervasive direct and indirect control over charitable organizations (Lim, $\mathrm{Ng}$, and Chang 2017; Tanaka 2002). Such direct and indirect control takes several forms such as the provision of funding, civil servants sitting on the board of directors of some charitable organizations, mandatory registration scheme for charities and a law that is designed to ensure that registered charities are apolitical in nature. Open and direct confrontation with registered charities is rare save for issues of mismanagement or registered charities which are religious organizations pursuing teachings that are deemed by the state to be extremist in nature. The reason for the lack of open confrontation is due to a legal framework which would not register a nonprofit organization as a registered charity if the organization engages in aims inconsistent with the state's view of public interest. Such nonprofit organizations also typically do not receive state funding. This aspect demonstrates the confrontational nature of the state's relationship with these nonprofit organizations. Through a close analysis of the laws, codes, media reports and academic literature on the charitable sector in Singapore, the central thesis of this paper is that the charitable sector in Singapore is essentially a state facilitated endeavor. 


\section{Nonprofit Organizations and Government Relations}

The present article locates Singapore's charitable sector within the literature on government and nonprofit organization relations. There are several typologies associated with the relationship between government and nonprofit organizations (Toepler et al. 2020). Two influential typologies are considered in this paper. First, Young conceptualised the relationship between government and nonprofit organizations as a complex connection which is either supplementary, complementary, or adversarial (Young 2000). According to Young, any one aspect of these descriptions may be applicable or even dominant at some historical moment. Young's model is based on different strands of economic theory. The supplementary model is predicated on nonprofits fulfilling public goods that are unsatisfied by government. Thus, private financing of public goods would lessen government expenditure. In relation to the complementary model, nonprofits are viewed as satisfying public goods which are not provided by the government. Under the complementary model, nonprofits are seen as partners to government by helping governments carry out the delivery of public goods. In this endeavor, nonprofits are largely funded by governments. Under the adversarial model of relations, nonprofits agitate government in terms of changes to public policy and accountability to the public. However, this is not a one-way street as government would try to influence nonprofit organizations in terms of regulation and responding to nonprofit advocacy.

Najam has offered an elegant conceptual framework for understanding nonprofit organisation relations with governments (Najam 2007). According to Najam, the framework may be summarized as cooperation, confrontation, complementary, and co-optation. While Najam's framework present some overlap with Dennis Young's work especially in relation to cooperation, confrontation and complementarity, Najam's model advances another aspect of this complex relationship i.e. co-optation. According to Najam, a co-optive relationship is when government and nonprofit organizations share similar strategies but may prefer different goals. Najam perceptively observes (Najam 2007):

The situation is unstable, or, contrived because it is the ends that are in conflict. As each side tries to change the goal preference of the other side, the discomfort is likely to be directly proportional to the power asymmetry. It is the power asymmetry that will decide whether, and which, side gives in or gives up - the instability is resolved as the relationship moves to one of the other [three models].

This paper analyses Singapore's charitable sector and nonprofit organizations through the lens of Najam's theoretical framework. The element of co-optation is 
particularly apt in the context of Singapore especially where the power asymmetry between the state and the charitable sector is so acute that the charitable sector is inevitably pushed into the cooperation and complementary model with the state. As will be demonstrated below, the confrontation aspect of the relationship between the charitable sector and state rarely ventures out in the open because the laws and regulations by design exclude certain kinds of nonprofit organizations from being registered as charities and that registered charities are by legal design meant to be apolitical in nature. The implication of framing this inquiry within Najam's model is that it reveals that the charitable sector in Singapore is essentially a state facilitated endeavor. For nonprofit organizations which pursue aims which are perceived by the state as not being in the public interest, they would not be able to gain a foothold as a registered charity.

\section{Early Benevolent Activities in Singapore: Self Help Enterprises as a Result of Failure of the State to Provide Public Goods}

The founding of modern Singapore dates from 1819 by Sir Thomas Stamford Raffles, who obtained the settlement of Singapore from the Sultan of Johore (Tang 2018). To make sense of the early benevolent activities in colonial Singapore, it is important to understand the population mix at that time. When Raffles arrived, Singapore was said to be inhabited predominantly by a small group of Orang Laut (Sea Peoples). As a major commercial centre, Singapore started to attract a large migrant population especially from China and India. Singapore's multi-racial population is categorized under Chinese, Malays, Indians, and 'Others' (Saw 1969).

Under the colonial government, each ethnic community took care of their own social welfare needs. The British government implemented an ethnic or dialectbased town plan so that they did not have to devote resources to dealing with immigrant issues (Maisharah 2008). The society functioned through '[a] system of self-government or ... "indirect rule"' under the British, where each community would govern itself through its own norms, enforced by local heads (Phang 1990; Wee 2004). As a result of the British's neglect of these immigrants, and their desire to find kinship in a foreign land, they formed clan associations, dialect associations and secret societies, to safeguard their own interests (O'Halloran, McGregregor-Lowndes, and Simon 2008; Prakash and Tan 2015). Within these associations, benevolent activities were driven by a class of wealthy merchant individuals. Thus, early benevolent activities were mainly self-help ethnic groups 
to deliver public goods to their respective communities because of the state's failure to deliver these public goods.

\section{Cooperative, Complementary, Co-optation and Confrontational: State Partners, Intermediaries, and Independents}

Under the complementary model, Najam postulates that where the goals of the government and nonprofit organizations are similar, they gravitate towards complementary arrangements (Najam 2007). This might blossom into cooperation especially in the context of provision of social services. Much of Singapore's charitable sector displays this cooperative and complementary aspects in relation to the state. Since Singapore achieved independence in 1965, the government has promoted the narrative of self-help, family and kin-group support guided community initiatives in meeting immediate social welfare needs. In 1995, the government formally mooted the idea of Many Helping Hands, which called for cooperation across all sectors of society in leading social change rather than merely taking the government's cue (Tarmugi 1995). The government's overarching aim is to cultivate a culture of self-reliance (Mathi and Sharifah 2011; Ng 2013). Braema Mathi and Sharifah Mohamed succinctly described the government's philosophy as follows:

Securing a good job is the most effective way of ensuring one's needs are sustainably met. The family is the next layer of support, followed by the community and lastly, the government.

In other words, the ideology of social services in Singapore is one of shared responsibilities between the individual, families, community, and the state acting as the last line of defence (Jones 2002; Pang and Wang 1996). This explains the government's philosophy of refraining from being a direct provider of welfare services (Chua 2010; Jones 2002). Instead, the government enables, through capacity building bodies (Jones 2002; Tan 2007), and funds various organizations previously known as Voluntary Welfare Organizations, and now rebranded as Social Service Agencies ('SSA') to provide welfare services (Rasthith and Tan 2019). The government acts as the coordinator, facilitator, and regulator of the providers of social services through such SSAs. In this context, the state has a cooperative and complementary relationship with SSAs to provide social services so much so that the SSAs are akin to partners of the state. While the state provides substantial funding, the government does not usually provide SSA with full funding. SSAs are 
expected to raise funds from the public so that this would build 'a foundation for shared responsibility where Government, people and private sectors work together to provide social service jointly' (Ang 2017). The resultant effect of this approach is a complex network of providers of social services which is known as the Many Helping Hands Approach to social welfare (Ang 2017; Rozario and Rosetti 2012). Hence, social services in Singapore are usually provided through a network of religious or ethnic based or non-religious SSAs with partial funding from the government (Ng and Sim 2012). Since the state provides funding to SSAs, the state exercises regulatory and management oversight over these SSAs (Jones 2002). This part of the relationship illustrates the element of co-optation between the state and the charitable sector where significant power asymmetry exists in terms of the possibility of the state withholding funding to charities. The level of control that the state wields over the SSAs is on a macro level in terms of policy directions and not on a micro everyday level. Generally, SSAs do have operational independence on how to provide the services if they meet the auditing standards of the state (Jones 2002). Presumably, charities which receive substantial funding from the state to deliver social services would not pursue aims inconsistent with the state's vision of public interest. In recent times, there seems to be a quiet retrenchment of the Many Helping Hands philosophy. Instead, there is a push for consolidation and profession alising the provision of social services within the charitable sector. Perhaps, the Singapore government's current approach is encapsulated in the quote by the CEO of a large charity saying: 'Consolidation means you have a few strong hands doing the heavy lifting' (Tan 2019).

However, it is important to note that not all the state's relationship with nonprofit organizations in Singapore is cooperative and complementary in nature (Chong 2005; Harding 2020b). Groups which focus on advocacy and issues which are regarded to be outside the state's agenda might not be granted any form of legal status. Thus, the government's relationship with these nonprofit organizations may be described as confrontational. In 2017, Lim, Ng and Chang categorized nonprofit organizations in Singapore into a three-fold grouping: State Partners, Intermediaries and Independents (Lim, Ng, and Chang 2017). According to this taxonomy, State Partners are closely affiliated to the state and typically consists of SSAs which enjoy both charitable and preferable tax treatments for their donors. These State Partners 'typically provide services that fall within the State's priorities and are fully or almost fully funded by the State to the extent that they are seen as junior partners of the State' (Lim, Ng, and Chang 2017). In contrast, Independents are not closely connected to the state and often pursue an agenda which may be contrary to the state's agenda or priorities. These may be pure advocacy groups like human rights group, anti-death penalty movement or LGBTQ activists. Independents usually do not receive any funding from the state and are often not 
formally registered as societies or companies. These Independents have a confrontational relationship with the state as their goals are antithetical to the state. In between State Partners and Independents are what Lim, $\mathrm{Ng}$ and Chang term as 'Intermediaries'. These Intermediaries carry out some work which falls within the state's agenda and receive some financial support from the state. Intermediaries are registered as societies or companies and some of them enjoy the status of being a charity or preferable tax status. These Intermediaries may engage in some advocacy work and call for a change of law. Thus, these Intermediaries may be in a cooperative, complementary, and sometimes co-optive relationship with state. The advocacy work represents the co-optive element where the Intermediaries try to subtly lobby for changes in the laws and policies of the state. But Intermediaries are careful not to let the advocacy aspects of their work become the main purpose of the organization lest they enter into a direct confrontation with the state and lose their funding and registration status as charities.

\section{Complementary and Co-optation: Codes and Regulation}

It is well-known that mismanagement and scandals cause a trust deficit which is harmful to the development of the charitable sector (Shapiro 2018). Hence, good governance is complementary to the vibrancy of the charitable sector. The current regulatory framework in relation to charities is achieved through a combination of statute and codes. This is consistent with the trend seen in other jurisdictions (Breen, Dunn, and Sidel 2017). The Commissioner of Charities has stated that the governance philosophy 'has shifted from a sole regulatory approach to that of co-regulation, initiating and acknowledging the partnership efforts of all the major stakeholders' (Ang 2019). Central to the governance structure of charities in Singapore is the Commissioner of Charities. The office of the Commissioner of Charities collaborates with the rest of government and the private sector to promote good governance. In terms of government input, the Commissioner works with representatives of various government ministries to regulate charities.

\subsection{Co-optation Through the Commissioner of Charities and Charities Legally Defined as Apolitical Organizations}

Charitable organizations in Singapore may take the form of companies limited by guarantee (Companies Act 2006) or trusts or societies (Societies Act 2014). Prior to 
the enactment of the Charities Act, charities were under the supervision of several authorities. This changed in 1983, when the Singapore enacted the Charities Act.

The centerpiece of the Charities Act was the formation of the Commissioner of Charities, modelled on the United Kingdom's Charity Commission, an office which administers the registration and supervision of charities. According to section 4(1) of the Charities Act, 2007, the statutory objectives of the Commissioner are to: (a) maintain public trust and confidence in charities; (b) promote good governance amongst charities; (c) promote the effective use of charitable resources; and (d) enhance the accountability of charities to donors, beneficiaries, and the general public. Further, according to section 4(2) of the same, the general function of the Commissioner includes determining whether institutions are or are not charities, identifying mismanagement and taking remedial or protective action in connection with mismanagement.

As part of its regulatory function, the Commissioner performs a gatekeeping function which is achieved via a mandatory registration requirement for all charities. This aspect of the regulation illustrates the government's efforts to control the sector (Guo and Zhang 2014). Viewing this aspect through the lens of Najam's model, the registration requirement represents the co-optation aspect of the state's relationship with nonprofit organizations. The registration requirement ensures that registered charities in Singapore pursue purposes which are consistent with the state's vision of the public interest and norms of the country. Under section 5(6) of the current version of the Charities Act, it is mandatory for charities to apply for registration within three months after its establishment. Once organizations apply for registration, the Commissioner is tasked with the function of determining whether the institutions are or are not properly regarded as charities, pursuant to section 4 of the Charities Act (2007). Under section 5(3A) of the same, the Commissioner is given an overriding power of refusal to register an institution as a charity if it appears that the institution's work will be contrary to the public interest or on such other ground as the relevant Minister may prescribe. Even if the organization has been registered, the Commissioner retains the power under section $5(3 \mathrm{~B})$ of the Charities Act to remove an institution from the register of charities if the continued registration of the institution as a charity is contrary to public interest or on such other ground as the Minister may prescribe. Therefore, the Commissioner is vested with the immense power to decide which organization may be a registered charity. The benefit of being a registered charity is that all registered charities enjoy automatic tax exemption on its income. Apart from tax exemption, registered charities appear to enjoy more credibility among members of the public (Harding 2020a).

In Singapore, a charity may take the legal form of either a company limited by guarantee, a society or a trust. There are registration requirements in relation to 
companies and societies but not to a trust. While the trust was commonly used in the past, modern charities in Singapore usually take the legal form of companies and societies (Leow 2012). Thus, there is a two-stage process to set up a registered charity. First, the organization must be set up using a recognised legal vehicle. Second, the organization would then have to apply to be a registered charity under the Charities Act. In Singapore, even before a nonprofit organization may apply for registration status, it might face formidable difficulties establishing itself as either a company or society. This is because the Registrar of Companies pursuant to section 20 of the Companies Act, and the Registrar of Societies pursuant to section 4 of the Societies Act may decline to register a nonprofit organization as either a company or society on the grounds that it is contrary to the public interest. Therefore, an organization may fail to register its existence as either a company or society before it may even consider applying to be registered as a charity. In the past, there were instances where an organization failed to register as a company or society because it was considered by the authorities to be against public interest. Organizations which have failed to obtained registration status as a company or a society include an online platform, New Naratif (Sin 2018) and a LGBTQ organization called People Like Us (Tanaka 2002).

In summary, the upshot of the law in this area is that the Commissioner, Registrar of Companies and Registrar of Societies are given an important gatekeeping function of deciding whether an organization has a legal form and if so, is deemed to be a charitable organization in Singapore. The law in this area appears to be a co-optation mechanism designed to prevent organizations which pursue objectives which challenge the state's vision of public interest from even gaining any form of legal status in Singapore be it a company or society. Without legal status, an organization is not able to open a bank account in its own name and faces formidable difficulties in raising funds.

Another interesting aspect of charity law in Singapore is the interplay between common law principles, the Charities Act and government policy in relation to the definition of charitable purposes. In Singapore, the definition of whether a purpose is regarded as charitable is ostensibly governed by the common law. Section 2 of the Charities Act defines "charitable purposes" as "purposes which are exclusively charitable according to the law of Singapore'. In other words, the statute explicitly references the common law of Singapore in relation to the question of whether a purpose is regarded as charitable. Singapore, being a former English colony, applies the well-known test articulated in Special Purposes of the Income Tax v John Frederick Pemsel (1891) ('Pemsel') for charitable purposes (Leow 2012). The United Kingdom has now transitioned to the Pemsel-plus categorisation by way of the Charities Act 2011 where there are thirteen descriptions of recognized charitable purposes (Leow 2012). In contrast, the Singapore courts still consistently 
apply the Pemsel classification (Independent State of Papua New Guinea v PNG Sustainable Development Program Ltd 2019; Koh Lau Keow and others v Attorney General 2014).

However, Singapore regulators have moved on to a modified Pemsel plus categorisation without an explicit amendment to the Charities Act (Leow 2012). In 2005, Prime Minister and Minister of Finance, Mr Lee Hsien Loong, said in the Annual Budget Speech:

First, I will expand the definition of 'charitable purposes'...I have decided to recognise the advancement of sport as a fifth charitable purpose, where the sport advances the health of individuals...Second, I will explicitly recognise as charitable purposes several purposes that we now group under 'other purposes beneficial to the community', to encourage the groups undertaking these activities, as well as encourage Singaporeans to donate to these groups. The purposes are (Government of Singapore 2005):

- the advancement of health

- the advancement of citizenship or community development;

- the advancement of the arts, heritage or science;

- the advancement of environmental protection or improvement;

- the relief of those in need by reason of youth, age, ill-health, disability, financial hardship or other disadvantage; and

- the advancement of animal welfare.

This was subsequently recognized in the Annual Report of the Commissioner of Charities for 2005, and the Charity Portal which a website maintained by the Commissioner. Hence, the Commissioner have now as a matter of practice affirmed an expanded definition of 'charitable purposes' (Charity Portal n.d.).

There are two observations in relation to the expanded meaning of charitable purposes. First, the expanded categories are identical to the Pemsel plus categories found in section 3 of the English Charities Act 2011 save for the omission of section 3(1)(h), on the 'advancement of human rights, conflict resolution or reconciliation or the promotion of religious or racial harmony or equality and diversity', and section 3(1)(1), on the 'promotion of the efficiency of the armed forces of the Crown, or of the efficiency of the police, fire and rescue services or ambulance services'. The omission of section 3(1)(h) is unsurprising given Singapore's history of advancing an Asian values approach to human rights. Hence, it is predictable that the policy makers have not regarded the advancement of human rights as a charitable purpose. Again, this omission is an illustration of the state's confrontational relationship with nonprofit organizations especially those which work to advance human rights. By legal design, advancement of human rights would 
probably not be regarded as a charitable purpose in Singapore. In relation to the exclusion of section 3(1)(1), it is speculated that there is no culture of benevolence in Singapore to promote the efficiency of armed forces, police, fire and rescue or ambulance services. Second, the recognition of the Pemsel plus categories without corresponding statutory amendments is probably a regulatory oversight. Since the Singapore courts have continued to apply Pemsel, it is hard to see the legal basis on which the Commissioner had proceeded to recognize the Pemsel plus categories without explicit judicial recognition.

Another interesting feature of Singapore charity law which illustrates the state's co-optive relationship with charities is that charities are conceived by legal design as apolitical organizations. This has roots in English common law (Bowman v Secular Society Ltd 1917; McGovern v Attorney-General 1982) and is implicitly entrenched by the Political Donations Act. There is English jurisprudence that charitable organizations cannot pursue political objectives as its main purpose. In recent times, the rule that charities may not engage in political activities have been relaxed in some jurisdictions (Lee 2015). However, the recent shift in jurisprudence in the Commonwealth is unlikely to affect Singapore due to its legislative framework. Under the section 2 of the Political Donations Act, an organization 'whose objects or activities relate wholly or mainly to politics in Singapore' may be declared by the Minister as a political organization. Once an organization is declared as a political association, it would not qualify as a charity. Hence, political associations will not enjoy tax relief or provide tax exemption to its donors. In fact, under section 12 of the Political Donations Act, political associations are statutorily precluded from receiving donations from foreigners and must disclose all donations including details of donors to the Registrar of Political Donations. The law in this area ensures alignment of the charitable sector with the state's objectives and prevents the charitable sector from entering the political sphere and challenging the government.

\subsection{Complementary and Co-optation: The Charity Council and Sector Administrators from Government Ministries}

One of the unique aspects of the governance structure in Singapore is the operation of the Charity Council, which was formed on 1 March 2007, alongside the Commissioner of Charities. The legal status of the Charity Council is enshrined in the Charities Act. Under section 4A and 4B of the same, its statutory functions are to: (i) advise the Commissioner on any question referred to it by the Commissioner; (ii) make recommendations to the Commissioner as it may think fit; and (iii) promote self-regulation and good governance standards in the charity sector. 
In forming the Charity Council, the state has co-opted leading lights in various sectors to co-regulate charities. The current composition of the Charity Council comprises distinguished individuals who are chosen for their expertise in accountancy, corporate governance, entrepreneurship, academia and law. Besides these distinguished individuals, representatives from the sector administrators of charities from numerous government ministries are included in the Charity Council. The Charity Council's significant contribution is the development of a Code of Governance which sets out principles and best practices in key areas of governance and management that charities are encouraged to adopt (Quah 2011). While compliance of the Code of Governance is not mandatory, the Charity Council has stated that the Code of Governance operates on the principle of 'comply or explain'. The Code of Governance may be seen as both complementary and cooptive in nature. Promotion of good governance ought to be viewed as being complementary with the overall goals of all charities. Or it can be viewed as subtle co-optation at play where the state is seeking to change the governance culture of charities. A possible reason for not entrenching the Code of Governance as statute is to give charities the discretion to prescribe their own internal governance structure and principles so long as the charities fulfill best practice standards. Apart from the Code of Governance, the Charity Council also organizes the Charity Governance Awards which recognizes charities that have adopted the highest standards of governance. The Charity Council's other initiatives include public education on safer giving and collaborative endeavors which connects charities for mutual support, learning of good practices and developing solutions to address common challenges. These efforts may be seen as situations where the state and charities are in a complementary relationship.

\section{Complementary Tax Policies: Generous Tax Relief}

Singapore's tax policy may be described as complementary to the charitable sector which serves the needs of the community. While ethnic based self-help groups continue to play an important role in Singapore (Siddique 2017), the Charities Act encourages donations to organizations which serve the Singapore society as a whole and not narrow sectoral interests by granting generous tax relief to donors. Under section 37 of the Income Tax Act, a taxpayer is entitled to deduct an amount equivalent to twice the sum of any donation of money made to any Institution of Public Character. To further encourage Singaporeans to give back to the community, the Minister of Finance has increased the tax deduction to 250\% until 31 
December 2023 (Ng 2021). It should be noted that this tax relief is only available to donations to an Institution of Public Character. Under section 3(1)(a) of the Charities (Institutions of a Public Character) Regulations, a separate category of Institution of Public Character was created where the organization must inter alia be: (i) a registered charity or an exempt charity in Singapore; and (b) its activities are exclusively beneficial to the community in Singapore as a whole and not confined to sectional interests or groups of persons based on race, belief or religion. This differs from the common law view of charity which has not defined charities as catering to non-sectional interests. Thus, not all charities may qualify as Institutions of Public Character. For example, a church or clan association would usually not be regarded as an Institution of Public Character because its activities are confined to groups of persons based on religion or race respectively. It follows that any corresponding donation to a church or clan association would not result in tax relief for the donor. The tax treatment in favour of Institution of Public Characters is easy to justify. Since the state provides substantial tax deductions to the donor, the donee must be an organization which serves all communities in Singapore and not just a narrow section of the community. The generous tax relief provided to donors of Institutions of Public Character is the starkest example of the Singapore government's policy of facilitating charitable activities beyond the narrow confines of religious and ethnic lines.

\section{Complementarity and Co-optation by the State Via Enabling Organizations}

In terms of being an enabler of charities, the Singapore government has set up various organizations to, inter alia, build capacity across the sector and consolidate fund raising to complement the charitable sector. One of the main organizations which enables voluntary welfare organizations providing social services is the National Council of Social Service ('NCSS'). NCSS works as a membership organization where members enjoy the following opportunities: (i) funding grants; (ii) networking; (iii) capacity and capability initiatives; (iv) essential services; (v) sector knowledge and landscape; and (vi) branding expertise. Since NCSS provides funding to its members, a cynical view of this organization is that NCSS is the state's instrument in the co-optation of the charitable space (Guo and Zhang 2014).

Another important enabling organization which complements the charitable sector is the National Volunteer and Philanthropy Centre ('NVPC'). Initially, NVPC was set up to promote volunteerism as well as to encourage the community to 
develop initiatives to help those in need. In recent times, NVPC has emerged as a crucial think tank and facilitator of charitable endeavors in Singapore.

As part of the overarching premise of Singapore as a 'City of Good', NVPC promotes volunteerism, an online giving platform, corporate giving and nurturing leadership capability in the non-profit sector. NVPC has also convened a series known as Colabs where diverse stakeholders comprising representatives from government, charities, corporations, donors and academics come together to collectively unpack complex social issues and attempt to propose holistic solutions. Thus, it can be said that NVPC's work complements the charitable sector.

The Community Foundation of Singapore ('CFS') is another illustration of NVPC's far-sighted leadership to build capacity and centralize fundraising efforts in Singapore within the charitable sector. Set up by NVPC in 2008 with the support of the state, CFS is a charitable organization primarily structured to raise funds for charities. CFS pools together donations from wealthy individuals by way of donor-advised funds (Hemel et al. 2021; Lim 2019). Thus, CFS may be described as complementary to the charitable sector as it facilitates private sector donations to charities.

It is interesting that the state has viewed CFS as a starter kit for wealthy individuals to set up private foundations. In other words, CFS provides an easy way for high-net-worth individuals to fulfil their philanthropic aims with the eventual ambition that these individuals will then set out fully fledged philanthropic foundations. The government demonstrated its support for CFS by sponsoring its start-up and administrative costs, up to a cap of $\$ \$ 10$ million (Lee 2008). CFS operates on a donor-advised fund model. Essentially, donor-advised funds are initiatives which people or companies may start to support their favourite causes (Gelles 2018). For example, a donor makes an irrevocable contribution to his or her favourite cause and a donor-advised fund is then set up in the donor's name to pursue this aim. While the legal title in these donor-advised funds vest in the organization, the donor has a huge say in determining the way the funds are disbursed. Since its inception, CFS has, according to its website, as of July 2020, set up 165 donor-advised funds, raised S\$197 million in donations and given out $\mathrm{S} \$ 122$ million in grants.

\section{Complementarity and Co-optation: Asian Headquarters of International Nonprofit Organizations}

The Singapore government has promoted the country as an international hub for nonprofit organizations to capitalize on its status as an international financial 
center (C. Tan 2011). Specifically, the Singapore government has created attractive conditions to woo certain international nonprofit organizations to be headquartered in Singapore. Since 2004, Singapore's Economic Development Board has been using a whole-of-government effort to facilitate international organizations planning to locate their Asian headquarters in Singapore by providing tax breaks and other incentives (Tan 2004; E. Tan 2011). The government developed supporting physical infrastructure, such as the Tanglin International Centre for clustering and shared services in order to be Asia's non-profit hub (Lim 2012). As a result of these efforts, Singapore has attracted many international nonprofit organizations such as World Wide Fund for Nature, Earth Hour, Mercy Relief and World Vision International to set up presence in Singapore. The rationale for encouraging nonprofit international organizations to be in Singapore is because their presence is seen to provide tangible and intangible benefits. In terms of tangible benefits, these include jobs nonprofit organizations bring to Singapore while the intangible benefits are the provision of international volunteer opportunities for the people living in Singapore. Thus, this aspect of the state providing favourable conditions to international nonprofit organizations to set up their headquarters in Singapore displays the state's complementary relationship with certain nonprofit organizations. Interestingly, not all international organizations are welcome by the authorities in Singapore. Nonprofit organizations such as Oxfam and human rights organizations that are seen to be engaged in forms of activism deemed to be incompatible with the legal structure and social norms of Singapore have not been given approval to set up headquarters in Singapore (Lim 2012; Tanaka 2002). This is the illustration of the state's co-optive relationship with certain nonprofit organizations which are regarded as furthering purposes not being in the public interest and social norms of Singapore.

\section{Conclusions}

The Singapore case study has located the state's relationship with charities through the Najam's framework of cooperation, complementarity, co-optation, confrontation. Complementarity is achieved via enacting a regulatory framework mainly by way of the Code of Governance promoted by the Charity Council. In terms of cooperation and complementarity, the state works closely and funds certain charities to provide social services. The state has also set up and funded various enabling organizations which builds capacity, consolidates fundraising and facilitates collaboration within the charitable sector by promoting volunteerism, online giving, corporate giving and nurturing leadership capability in the non-profit sector. Again, these are examples of the state in a complementary 
relationship with charities. Besides setting up enabling organizations, the government has also used strategic tax policy to nudge the charities in Singapore from a sector historically premised on ethnic and religious lines to facilitating charities which serve the wider community by incentivizing donations to these charities. Cooperative and complementary efforts with the charitable sector are also demonstrated by the state setting up organizations such as the Community Chest and CFS. Other cooperative and complementary efforts include encouraging certain international nonprofit organizations to set up their headquarters in Singapore. However, an overarching and omnipresent theme in the state's relationship with the charitable sector is the element of co-optation. While the state's rationale for regulation is to protect public trust and confidence, the laws and policies are designed in a manner to ensure that charities and international nonprofit organizations situated in Singapore do not challenge the state's vision of what is in the public interest in Singapore. By its very design, Singapore's charity law ensures that registered charities must not pursue overt political aims. This represents the co-optive element by the state in relation to the charitable sector. Many of the charities which provide social services and enabling organizations receive funding from the state and have civil servants sitting on their boards. Unsurprisingly, these organizations are heavily guided by the state's agenda. Organizations which pursue an agenda, which in the not regarded as in the common good of Singapore would not be able to register itself as charities and enjoy corresponding benefits. Viewed as a whole, it is fair to say that the charitable enterprise in Singapore is very much a state facilitated endeavor.

Acknowledgments: The author would like to thank the anonymous referees, editors of Nonprofit Policy Forum, Barry Crown, Matthew Harding, Rebecca Lee, Vincent Ooi, John Picton, Marina Tan Harper, Eugene Tan, Tan Sook Yee and Ying Wang for their helpful comments on earlier drafts of the paper. I am also grateful to my research assistants, Terence Yeo, Soh Kian Peng and Glenn Ng for their excellent work.

\section{References}

Ang, B. L. 2017. Singapore's "Many Helping Hands." In Civil Society \& the State in Singapore, edited by C. Soon, and G. Koh, 134-51. Singapore: World Scientific Publishing Company.

Ang, H. S. 2019. Co-Regulation: Future of Governance in Charities. Singapore: The Business Times. Breen, O.B., A. Dunn, and M. Sidel. 2017. "Regulatory Waves." In State Regulation and SelfRegulation Policies in the Nonprofit Sector, edited by O. B. Breen, A. Dunn, and M. Sidel, 1-20. Cambridge: Cambridge University Press.

Bowman v Secular Society Ltd. 1917. A.C. 406 (Eng.). 
Centre for Asian Philanthropy and Society. 2020. Doing Good Index 2020.

Charities Act (Cap 37, 2007 Rev Edn).

Charity Portal. n.d. About Charities and IPCS. Also available at https://www.charities.gov.sg/ setting-up-a-charity/Pages/About-Charities-And-IPCs.aspx.

Charities Unit, Ministry of Culture, Community and Youth. 2019. Commissioner of Charities Annual Report 2019.

Chong, T. 2005. "Civil Society in Singapore: Popular Discourses and Concepts.” Sojourn: Journal of Social Issues in Southeast Asia 20 (2): 273-301.

Chua, B. H. 2010. "Emerging Issues in Developmental Welfarism in Singapore." In The Crisis of Welfare in East Asia, edited by J. Lee, and K. W. Chan, 27-42. Lanham: Lexington Books.

Companies Act (Cap 50, 2006 Rev Edn).

Gelles, D. 2018. How Tech Billionaires Hack Their Taxes with a Philanthropic Loophole. United States: The New York Times.

Government of Singapore. 2005. Singapore Parliamentary Debates, Official Report, Vol. 79.

Guo, C., and Z. Zhang. 2014. "Understanding Nonprofit Advocacy in Non-western Settings: A Framework and Empirical Evidence from Singapore." Voluntas 25: 1151-74.

Harding, M. 2020a. "Charity and Law: Past, Present and Future." Singapore Journal of Legal Studies 2020: $564-80$.

Harding, M. 2020b. "Independence and Accountability in the Charity Sector." In Debates in Charity Law, edited by J. Picton, and J. Sigafoos, 13-36. Oxford: Hart Publishing.

Hemel, D., J. Bankman, and P. Crest. 2021. "Are Donor-Advised Funds Good for the Nonprofit Sector." The Exempt Organization Tax Review 87: 287-303.

Independent State of Papua New Guinea v PNG Sustainable Development Program Ltd 2019. S.G.H.C. 68.

Jones, D.S. 2002. "Welfare and Public Management in Singapore: A Study of State and Voluntary Sector Partnership." Asian Journal of Public Administration 24 (1): 57-85.

Koh Lau Keow v Attorney-General 2014. 2 S. L. R. 1165.

Lee, L. 2008. Foundation Seeks Donations of \$1M or More. Singapore: The Straits Times.

Lee, R. 2015. “Charity without Politics? Exploring the Limits of 'Politics' in Charity Law." Journal of Civil Society 11 (3): 271-82.

Leow, R. 2012. “Four Misconceptions About Charity Law in Singapore.” Singapore Journal of Legal Studies: 37-54.

Lim, C., M. Ng, and C. M. Chang 2017. "Building a Vibrant and Diverse Civil Society - Limitations and Possibilities." In Civil Society \& the State in Singapore, edited by C. Soon, and G. Koh, 153-185. Singapore: World Scientific Publishing Company.

Lim, P. 2012. Money-mad Singapore Aims to Become Non-profit Hub. France: AFP.

Lim, V. 2019. DAFs Still Quite New Concept: Charities Index. The Business Times.

Maisharah, S. 2008. "Tracing Singapore's Social Sector." Social Space: 16-22.

Mathi, B., and M. Sharifah. 2011. Unmet Social Needs in Singapore: Singapore's Social Structures and Policies, and Their Impact on Six Vulnerable Communities. Singapore: Lien Centre for Social Innovation, Singapore Management University.

McGovern v Attorney-General. 1982. Ch. 321 (Eng.).

Najam, A. 2007. "The Four-Cs of Third Sector - Government Relations." Nonprofit Management \& Leadership 10 (4): 375-96.

Ng, I., and H. Sim. 2012. "Funding and Remuneration in Social Services: Lessons from Singapore." Administration in Social Work 36 (3): 280-301. 
Ng, I. 2013. "Social Welfare in Singapore: Rediscovering Poverty, Reshaping Policy." Asia Pacific Journal of Social Work and Development: Poverty and Social Work: Experiences from some Asian and Oceania Countries 23 (1): 35-47.

Ng, M. 2021. Budget 2021: \$20M Fund to Match Comchest Donations Raised Through Spontaneous Acts of Giving. Singapore: The Straits Times.

O’Halloran, K., M. McGregregor-Lowndes, and K. W. Simon. 2008. Charity Law Social Policy: National and International Perspectives on the Functions of the Law Relating to Charities. Springer: Netherlands.

Pang, G. C., and H. L. Wang. 1996. Welfare - where Does Govt's Role End and the VWO's Begin? Singapore: The Straits Times.

Phang, A. 1990. The Development of Singapore Law: Historical and Socio-Legal Perspectives. Singapore: Butterworths.

Prakash, R., and P. Tan. 2015. Philanthropy on the Road to Nationhood in Singapore. Asia Centre for Social Entrepreneurship \& Philanthropy, NUS. Also available at https://www.issuelab. org/resources/23702/23702.pdf.

Quah, M. 2011. Charities Get Refined Code of Governance. Singapore: The Business Times.

Rashith, R., and T. Tan. 2019. New Name for Voluntary Welfare Organizations - Social Service Agencies. Singapore: The Straits Times.

Rozario, P. A., and A. L. Rosetti. 2012. ““Many Helping Hands”: A Review and Analysis of Long-Term Care Policies, Programs, and Practices in Singapore." Journal of Gerontological Social Work 55 (7): 641-58.

Saw, S. H. 1969. “Population Trends in Singapore, 1819-1967." Journal of Southeast Asian History 10 (1): 36-49.

Shapiro, R. 2018. "Philanthropists in Asia: What Do They Want? What Do They Get?" In Pragmatic Philanthropy: Asian Charity Explained, edited by R. Shapiro, M. Mirchandani, and H. Jang, 85-100. Netherlands: Springer Open.

Siddique, S. 2017. "The Future of Ethnic-Based Civil Society in Singapore." In Civil Society \& the State in Singapore, edited by C. Soon, and G. Koh, 188-201. Singapore: World Scientific Publishing Company.

Sin, Y. 2018. New Naratif Funded by a Number of Foreigners and Clearly Has a Political Agenda: Acra. Singapore: The Straits Times.

Societies Act (Cap 311, 2014 Rev Edn).

Tanaka, Y. 2002. "Singapore: Subtle NGO Control by a Developmentalist Welfare State." In The State and NGOs [:] Perspective from Asia, edited by Y. Tanaka, and S. Shigetomi, 200-221. Singapore: Institute of Southeast Asian Studies.

Tan, C. 2011a. Philanthropists Forum 2011; Tapping S'pore as Asian Hub for Philanthropy. Singapore: The Straits Times.

Tan, E. 2011b. The State of Play of CSR in Singapore. Singapore: Lien Centre for Social Innovation.

Tan, N. T. 2007. "Regulating Philanthropy [:] The Legal and Accountability Framework for Singapore Charities.” Asia Pacific Journal of Social Work and Development 17 (1): 69-78.

Tan, T. 2004. Singapore Woos Non-profit Organizations. Singapore: The Straits Times.

Tan, T. 2019. From 'Many Helping Hands' to Fewer and Stronger Hands? Singapore: The Straits Times.

Tang, H. W. 2018. "From Waqf, Ancestor Worship to the Rise of the Global Trust: A History of the Use of the Trust as a Vehicle for Wealth Transfer in Singapore." lowa Law Review 103(5):

2263-2292. 
Tarmugi, A. 1995. Statement by Mr Abdullah Tarmugi, Acting Minister for Community Development, at the World Summit for Social Development Copenhagen, Denmark, on 10 March 1995 at 5.00 PM (Singapore Time). Singapore: National Archives of Singapore Library.

Toepler, S., A. Zimmer, K. Levy, and C. Frölich. 2020. "Beyond the Partnership Paradigm: Toward an Extended Typolog of Government/Nonprofit Relationship Patterns." In Paper Presented at Author's Workshop for the 50th Anniversary Special Issue of Nonprofit and Voluntary Sector Quarterly. Online, Novem.

Wee, A. 2004. "Where We Are Coming From: The Evolution of Social Services and Social Work in Singapore." In Social Work in Context: A Reader, edited by K. Mehta, and A. Wee, 39-40. Singapore: National University of Singapore.

Young, D. R. 2000. "Alternative Models of Government-Nonprofit Sector Relations: Theoretical and International Perspectives." Nonprofit and Voluntary Sector Quarterly 2000 29 (1), 149-172. 